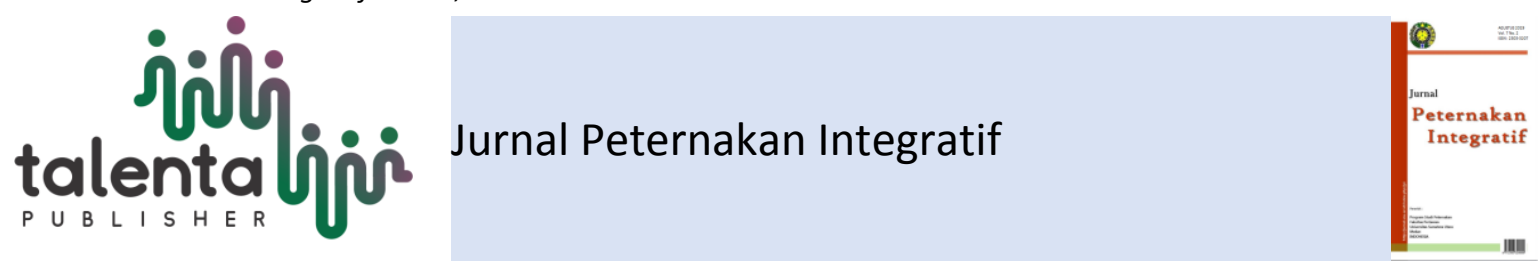

\title{
Corn Substitution By Using Cassapro (Cassava Protein) On Kampung Chicken Carcass
}

\author{
Hans Yoppi Sinaga, Iskandar Sembiring , Armyn Hakim Daulay, Ma'ruf Tafsin, and Nevy Diana \\ Hanafi \\ Animal Production Study Program, Faculty of Agriculture, Universitas Sumatera Utara, Medan 20155, \\ Indonesia \\ *Email: iskmilala@yahoo.co.id
}

\begin{abstract}
This research aimed to determine the ability of cassapro to substitute corn in feed on kampung chicken carcass. The research was conducted from December 2015 until March 2016. Experimental design used was completely randomized design (CRD) with 5 treatments and 4 replications. Each treatment consists of cassapro $\mathrm{P}_{0}(0 \%) \mathrm{P}_{1}(10 \%) \mathrm{P}_{2}(20 \%) \mathrm{P}_{3}(30 \%) \mathrm{P}_{4}(40 \%) .100$ kampung chicken was used this research. Parameters were cut weight, , carcass weight, and percentage of carcass.

The results showed that there were no signifiant effect on cut weight, carcass weight and percentage of carcass due to the administration of cassapro.
\end{abstract}

Keywords : cassapro, feed, kampung chicken, cut weight, carcass weight Received 10 May 2019|Revised 10 July 2019| Accepted 1 August 2019

\section{Introduction}

Feed is the highest cost component in livestock business, including intensive chicken farming. The high cost of animal feed has made it difficult for farmers to get proper food for livestock.

Corn is the main energy source for livestock because the corn starch content is more than $60-80 \%$ and is easily digested because the crude fiber content is relatively low. However, corn price is expensive so a good solution to reduce feed price by using corn substitution with other feed ingredient such as cassapro which is fermented cassava [1]. 
The advantage of using cassava as animal feed, among others, is that its price is relatively cheap compared to corn, available and its starch content is high so that it can be used as a dissolved carbohydrate [2]. Fermenting by using microorganisms such as Aspergillus niger or Lactobacillus sp [3] caused increased on protein content than the original ingredient. In this research, cassapro can be used as an additional ingredient in animal feed, especially poultry.

The addition of cassapro also give other benefits because if added to the main animal feed can increase the digestibility for the feed. This is due to the ability of Aspergillus niger to produce digestive enzymes such as cellulase, amylase, protease, phytase, and mananase which can help digest animal feed.

\section{Methods}

This research conducted at the Laboratory of Animal Biology, Animal Husbandry Study Program, Faculty of Agriculture, University of North Sumatra starting from December 2015 to March 2016.

This research used 100 chickens with a body weight range ranging from 40-45 g/ head. The ration feed ingredients consist of corn, soybean meal, coconut meal, bran, fish meal, oil, premix, A. Niger, drinking water, medicines, vitamins and vaccines, disinfectants, namely rodalon. The cages are 20 plots with sizes $(1 \times 1 \times 0.5 \mathrm{~m})$, drinking and feeding places each of 20 pieces, electric balance scales and salter scales. The research method used was Completely Randomized Design (CRD) with 5 treatments and 4 replications each replication consisted of 5 animals. The treatments studied were as follows:

$\mathrm{P} 0=$ Control ration with $60 \%$ corn without cassapro

$\mathrm{P} 1=$ Ration with $50 \%$ corn and $10 \%$ cassapro

P2 $=$ Ration with $40 \%$ corn and $20 \%$ cassapro

P3 = Ration with $30 \%$ corn and $30 \%$ cassapro

P4 = Ration with $20 \%$ corn and $40 \%$ cassapro

While the test was obtained from:

$\mathrm{T}(\mathrm{n}-1) \geq 15$

$5(\mathrm{n}-1) \geq 15$

5 n $-5 \geq 15$

$\mathrm{n} \geq 4$

The treatment arrangement is as follows:

$\begin{array}{llll}\mathrm{P}_{0} \mathrm{U}_{1} & \mathrm{P}_{1} \mathrm{U}_{1} & \mathrm{P}_{2} \mathrm{U}_{1} & \mathrm{P}_{3} \mathrm{U}_{1} \\ \mathrm{P}_{3} \mathrm{U}_{2} & \mathrm{P}_{0} \mathrm{U}_{2} & \mathrm{P}_{1} \mathrm{U}_{2} & \mathrm{P}_{2} \mathrm{U}_{2}\end{array}$




$\begin{array}{llll}\mathrm{P}_{4} \mathrm{U}_{3} & \mathrm{P}_{1} \mathrm{U}_{3} & \mathrm{P}_{0} \mathrm{U}_{3} & \mathrm{P}_{1} \mathrm{U}_{4} \\ \mathrm{P}_{4} \mathrm{U}_{4} & \mathrm{P}_{3} \mathrm{U}_{2} & \mathrm{P}_{2} \mathrm{U}_{4} & \mathrm{P}_{0} \mathrm{U}_{4} \\ \mathrm{P}_{4} \mathrm{U}_{1} & \mathrm{P}_{4} \mathrm{U}_{2} & \mathrm{P}_{3} \mathrm{U}_{3} & \mathrm{P}_{3} \mathrm{U}_{4}\end{array}$

The linear method used for non factorial Randomized Complete Design (RAL) was:

$\mathrm{Yij}=\mu+\tilde{\mathrm{O}} \mathrm{i}+\sum \mathrm{ij}$

Yij $=$ Value of observations obtained from the experimental unit from the second treatment and the test to $\mathrm{j}$

$\mu=$ Average / Middle Value

$\tilde{O} \mathrm{i}=$ Effects of treatment

$\sum \mathrm{ij}=$ the effect of the error of the first treatment trial and the jth test

\section{Results and Discussion}

\subsection{Cut Weight}

Cut weight is the weight obtained by weighing chicken weight after being fasted for 12 hours. Cut weight needs to be considered the quality and quantity of rations consumed, so that good growth is obtained [3] . The following is the average weight of slaughter of chicken with cassapro (Cassava protein).

Table 1. Data on slaughter weight of 12 weeks old chicken (g / head)

\begin{tabular}{lllllll}
\hline \multirow{2}{*}{ Treatments } & \multicolumn{6}{l}{ Cut Weight $(\mathrm{g})$} \\
\cline { 2 - 7 } & $\mathrm{U} 1$ & $\mathrm{U} 2$ & $\mathrm{U} 3$ & $\mathrm{U} 4$ & Average & S.Deviation \\
\hline P0 & 972.67 & 841.67 & 871.67 & 853.00 & 884.75 & 59.90 \\
P1 & 925.00 & 890.00 & 859.33 & 860.00 & 883.58 & 31.10 \\
P2 & 863.33 & 895.00 & 830.00 & 1048.33 & 909.17 & 96.50 \\
P3 & 833.33 & 768.33 & 770.00 & 860.00 & 807.92 & 46.06 \\
P4 & 895.00 & 723.33 & 925.00 & 890.00 & 858.33 & 91.32 \\
\hline
\end{tabular}

From this study it was found that the highest average cutting weight was found in P2 (Feed rations $40 \%$ corn was replaced by $20 \%$ cassapro) with an average of 909.17 followed by P0, P1, P4 and P3. This states that giving $20 \%$ cassapro flour gives higher results compared to other treatments. Value differences can be caused by differences in the growth of native chickens during maintenance. This is in accordance with [4] statement, whom stated animal growth is influenced by animal species, age , ration quality and environment. 
Table 2. Results of analysis of variants Weight loss of native chickens

\begin{tabular}{lllllll}
\hline SK & dB & JK & KT & Fhit & \multicolumn{2}{c}{ F Tabel } \\
\hline & & & & & 0.05 & 0.01 \\
\hline Treatment & 4 & 2836143.35 & 709035.84 & $0.93^{\text {tn }}$ & 3.24 & 5.29 \\
Galat & 15 & 11411636.12 & 760775.74 & & & \\
Total & 19 & 14247779.46 & 1469811.58 & & & \\
\hline tn $=$ different $/$ not real & & & &
\end{tabular}

tn $=$ different $/$ not real

From the table above, it was found that giving cassapro to free-range chickens had no significant effect on cut weight. This can be caused by the low response of the body of native chickens to the content of feed ingredients found in cassapro. The maximum response of free-range chicken is in P2 with only $20 \%$ cassapro, which states that the maximum limit of casappro giving to free-range chicken is $20 \%$.

\subsection{Carcass weight}

Carcass weight is the body weight of chickens that have been slaughtered after being separated by blood, feathers, head to the base of the neck, legs to the limits of the knee and internal organs except the kidneys and lungs [5]. The following is the average carcass weight of native chickens with cassapro (Cassava protein).

Table 3. Data on carcass weight of free-range chicken (g/ head)

\begin{tabular}{lllllll}
\hline \multirow{2}{*}{ Treatment } & \multicolumn{2}{l}{ Carcass Weight $(\mathrm{g})$} & & \multirow{2}{*}{ S.Deviation } \\
\cline { 2 - 6 } & U1 & U2 & U3 & U4 & Average & \\
\hline P0 & 729.25 & 631.25 & 653.75 & 639.75 & 663.50 & 38.80 \\
P1 & 693.75 & 667.50 & 648.03 & 653.60 & 665.72 & 17.67 \\
P2 & 655.73 & 683.17 & 633.63 & 796.62 & 692.29 & 62.74 \\
P3 & 633.33 & 591.62 & 587.37 & 659.28 & 617.90 & 29.89 \\
P4 & 680.58 & 548.17 & 705.83 & 676.13 & 652.68 & 61.39 \\
\hline
\end{tabular}

From the above research, it can be seen that the average weight of chicken carcass was on chicken given $20 \%$ cassapro flour (P2) which is 692.29 , this figure was $76 \%$ of the cut weight. This is the case with the statement [6], whom stated that the normal carcass weight is $60-75 \%$ of cut weight.

The high and low carcass weight is influenced by the amount of cut weight of livestock. This is consistent with the statement of Soeparno [7], whom stated that carcass weight increases with increasing life weight, but the percentage of non carcasses such as skin, blood, small intestine and liver decreased. 
Carcass weight is influenced by weight, so a large live weight will be followed by a large carcass weight and vice versa. As stated by [3], whom stated that the high carcass weight was supported by the final live weight as an addition to the weight of the person concerned. [8[ also stated that the carcass weight produced is influenced by several factors, namely age, sex, slaughter weight, body weight and conformation, fat, quality and quantity of rations and types of livestock kept.

From the research above, it can be seen that the administration of cassapro can increase cutting weight, carcass weight, and carcass percentage. This can be influenced by the presence of good nutritional content in cassapro which can be tolerated by the body of native chickens.

Table 4. Results of analysis of variants Weight of chicken carcasses

\begin{tabular}{lllllll}
\hline SK & dB & JK & KT & Fmeasured & F Table \\
\hline & & & & & 0.05 & 0.01 \\
\hline Treatment & 4 & 1628576.17 & 407144.04 & $0.93^{\text {tn }}$ & 3.24 & 5.29 \\
Galat & 15 & 6553070.56 & 436871.37 & & & \\
Total & 19 & 8181646.73 & 844015.41 & & & \\
\hline
\end{tabular}

tn $=$ different $/$ not real

From the analysis table of the variance above, it can be seen that the administration of cassapro flour to free-range chicken has a not significant effect on carcass weight. It is seen that F Hit (0.93) < FTabel 0.05 (3.24). This can occur due to the nutrient content in cassapro can not be $100 \%$ tolerated by the body of the village chicken.

\subsection{Carcass percentage}

The percentage of carcass is the most important factor for assessing livestock production, because production is closely related to live weight, where the weight increases, the carcass production will increase [3]. The following is the average carcass weight of native chickens with cassapro (Cassava protein). 
Table 5. Data on percentage of carcass of free-range chicken (\%)

\begin{tabular}{lllllll}
\hline \multirow{2}{*}{ Treatment } & \multicolumn{2}{l}{ Carcass percentage (\%) } & \multirow{2}{*}{ Deviation S } \\
\cline { 2 - 5 } & $\mathrm{U} 1$ & $\mathrm{U} 2$ & $\mathrm{U} 3$ & $\mathrm{U} 4$ & Mean & \\
\hline P0 & 7.5 & 7.5 & 7.5 & 7.5 & 7.5 & 1 \\
P1 & 7.5 & 7.5 & 7.5 & 7.6 & 7.5 & 47 \\
P2 & 7.6 & 7.6 & 7.6 & 7.6 & 7.6 & 21 \\
P3 & 7.6 & 7.7 & 7.6 & 7.6 & 7.6 & 43 \\
P4 & 7.6 & 7.6 & 7.6 & 7.6 & 7.6 & 21 \\
\hline
\end{tabular}

The percentage of carcass is the result of the division between carcass weights and live weight multiplied by $100 \%$. From the table above it can be seen that the highest percentage is found in P3 then followed by P2, P4, P1 and P0. This means that if it is reviewed from the carcass percentage, the percentage of carcass on P3 is the best percentage of all treatments. Meanwhile, if seen from the cutting weight P3 (860.00) and carcass weight P3 (617.9) when compared with P2, which is the highest treatment of cutting weight (909.17) and carcass weight (692.28). but when viewed from the percentage of carcass the highest value is $\mathrm{P} 3$. This shows that in $\mathrm{P} 2$ this weight occurs because there is a difference in the amount between the divisor (carcass weight) and the divided (live weight). According to [9[, fats and innards are a by-product that is not calculated in the percentage of carcass, if fat is high then the percentage of carcass will be low.

The difference in carcass percentage between treatments can be influenced by weight, food and genetics. Genetic which gives a $30 \%$ effect shows that there is a limit on the response of the body of kampong chicken to cassapro given. This is in accordance with the statement of [10], which stated that the percentage of carcass is influenced by nation, age, sex, weight and food. The percentage of young carcasses is lower than older chickens and the percentage of male chickens is greater than the percentage of females producing more skin and abdominal fat than males. [3] also stated that the percentage of carcass is an important factor for assessing livestock production, because production is closely related to live weight, where the weight gain increases, the carcass production increases.

The difference in the carcass percentage above is also seen in the following table annova.

Table 6. The results of variance analysis of the percentage of chicken carcass

\begin{tabular}{lllllll}
\hline \multirow{2}{*}{ SK } & dB & JK & KT & Fmeasured & \multicolumn{2}{l}{ F Table } \\
\cline { 5 - 7 } & & & & & & \\
\hline Treatment & 4 & 2.15 & 0.53 & $0.93^{\text {tn }}$ & 3.24 & 5.01 \\
Galat & 15 & 8.61 & 0.57 & & & \\
Total & 19 & 10.77 & & & & \\
\hline tn $=$ different / not real & & & & &
\end{tabular}

tn $=$ different $/$ not real 
FromTable 8, it can be seen that Fhit (0.937) < from F Table 0.05 (3.24). From this it can be concluded that in general the administration of cassapro flour does not have a very significant effect on the percentage of carcasses of kampong chicken in general.

\subsection{Recapitulation of Research Results}

The research recapitulation of cut weight, carcass weight and carcass percentage can be seen in Table 9 below.

\section{Parameter}

Treatments Cut Weight $(\mathrm{g})$ Carcass Weight $(\mathrm{g}) \quad$ Percentage of Carcass $(\mathrm{g})$

\begin{tabular}{llll}
\hline P0 & $884.75 \mathrm{tn}$ & $663.50 \mathrm{tn}$ & $74 \%$ tn \\
P1 & $883.58 \mathrm{tn}$ & $665.72 \mathrm{tn}$ & $75 \%$ tn \\
P2 & $909.17 \mathrm{tn}$ & $692.29 \mathrm{tn}$ & $76 \%$ tn \\
P3 & $807.92 \mathrm{tn}$ & $617.90 \mathrm{tn}$ & $76.4 \% \mathrm{tn}$ \\
P4 & $858.33 \mathrm{tn}$ & $652.68 \mathrm{tn}$ & $76 \% \mathrm{tn}$ \\
\hline
\end{tabular}

\section{Conclusions}

From the study it can be concluded that the cassapro administration in rations have a non significant effect on cutting weight, carcass weight and carcass percentage. How ever, 20 percent of cassapro could be used to replace $40 \%$ of corn in the ration. 


\section{References}

[1] Boonop, K., W. Metha, N. Ngarmnit and W. Sadudee. 2009. Enriching nutritive value of cassava root by yeast fermentation. Sci. Afri. J. 66(5): $629-633$.

[2] Mathius, I. W., Sinurat AP. 2001. Pemafaatan bahan pakan inkonvensional untuk ternak. Wartazoa11 (12): 20-31.

[3] N Ginting. 2018. Comparison of isolate dadih with yeast dadih in improving nutrition quality of Cassava Waste (CW). IOP Conf Series: Earth and Env Science 141 (2018) 012008.

[4] Blakely, D dan D.H. Bade 1991. Ilmu Perternakan. Edisi ke-4. Penerjemah : Bambang Srigandono. Gadjah Mada University Press, Yogyakarta.

[5] Mansjoer, S.S. 2003. Potensi ayam buras di Indonesia. Makalah Semiloka pengkajian Pengembangan Produksi Bibit Ayam Buras dan Itik, Cisarua-Bogor, Tanggal 11- 12 Desember 2003.

[6] Murtidjo, B.A. 1994. Mengelola Ayam Kampung. Kanisius, Yogyakarta.

[7] Siregar, E. 2002. Pengaruh Pemberian Tepung Tanjung (Minusops elengi L) dalam Ransum terhadap Performans Kelinci Lokal Umur 8 - 16 Minggu. Skripsi Jurusan Peternakan Fakultas Pertanian, Universitas Sumatera Utara, Medan

[8] Hartadi, H. 2005. Tabel Komposisi Pakan Untuk Indonesia. Gajahmada University Press.Yogyakarta.

[9] Respon Pertumbuhan Ayam Kampung dan Ayam Silangan Pelung Terhadap Ransum Berbeda Kandungan Protein, JITV. Vol. 4(1): 28-34

[10] Sarwono. B. 2005. Beternak Ayam Buras Pedaging dan Petelur. Edisi Revisi. Jakarta 